\title{
Treatment Sequencing After Failure of the First Biologic in Cost-Effectiveness Models of Psoriasis: A Systematic Review of Published Models and Clinical Practice Guidelines
}

\author{
Josephine Mauskopf $\cdot$ Miny Samuel • \\ Doreen McBride • Usha G. Mallya • \\ Steven R. Feldman
}

Published online: 28 January 2014

(C) The Author(s) 2014. This article is published with open access at Springerlink.com

\begin{abstract}
Objectives To analyse the treatment sequencing assumptions after failure on a first-line biologic in costeffectiveness models of treatment of moderate to severe plaque psoriasis, and to compare them with the most recent treatment guidelines.

Methods A systematic search of MEDLINE, Embase, EconLit and the Cochrane Library databases used free text and Medical Subject Headings terms including psoriasis, biologic therapies indicated for psoriasis, and all types of
\end{abstract}

Electronic supplementary material The online version of this article (doi:10.1007/s40273-014-0130-5) contains supplementary material, which is available to authorized users.

J. Mauskopf $(\square)$

RTI Health Solutions, 3040 Cornwallis Road, Research Triangle Park, NC 27709, USA

e-mail: jmauskopf@rti.org

M. Samuel · D. McBride

RTI Health Solutions, 2nd Floor, The Pavilion, Towers Business Park, Wilmslow Road, Didsbury, Manchester M20 2LS, UK

U. G. Mallya

Novartis Pharmaceuticals Corporation, 1 Health Plaza,

East Hanover, NJ 07396, USA

\section{S. R. Feldman}

Department of Dermatology, Wake Forest University School of Medicine, 4618 Country Club Road, Winston-Salem, NC 27104, USA economic evaluations. Two researchers performed 2-level abstract screening for articles meeting pre-specified inclusion criteria. Assumptions about treatment pathways after first-line biologic failure in the cost-effectiveness models were analysed. A second systematic search was performed for psoriasis clinical practice guidelines. Sequence assumptions were compared with treatment guideline recommendations.

Results Of 25 cost-effectiveness modelling studies identified, ten estimated the incremental cost per responder; time horizons varied (12 weeks-18 months) and treatment sequencing was not considered. In 15 studies where treatment sequencing was considered, with time horizons up to 10 years, five studies included only a switch to nonsystemic therapy or best supportive care after first-line biologic failure. Another five of the 15 treatment-pathway studies were available only as abstracts with no details of the sequence assumptions. In five of the 15 studies, first-line biologic failure was followed by second-line biologic monotherapy, one of the recommendations in current treatment guidelines. In only one of these five studies was the efficacy of the second-line biologic adjusted downwards, compared with first-line treatment. Only one of these studies considered dose titration with a first-line biologic and none combination therapy (biologic plus methotrexate or phototherapy) after first-line biologic failure, as recommended in some treatment guidelines.

Conclusions Cost-effectiveness models of first-line biologics for moderate to severe plaque psoriasis either do not include subsequent treatment regimens or include only some of the regimens recommended in current treatment guidelines. Results may be sensitive to assumptions about treatment sequencing and the choice and efficacy of subsequent treatment regimens. 


\section{Key Points For Decision Makers}

Many patients with moderate to severe plaque psoriasis fail treatment with first-line biologics.

Treatment guidelines recommend titration of the firstline biologic or switching to a second-line biologic or to combination therapy with a biologic and an immunosuppressant.

Studies indicate that switching to a second biologic or combination therapy with an immunosuppressant after failure of the first biologic can be effective.

Current cost-effectiveness models of first-line biologics are limited in their inclusion of subsequent treatments.

The results of the cost-effectiveness model may be sensitive to the treatment pathway that is assumed and to the efficacy of subsequent treatments.

Including recommended treatment sequencing pathways and assessing the sensitivity of the results to alternative treatment sequencing pathways will increase the usefulness of the results to health care decision makers.

\section{Introduction}

Chronic plaque psoriasis is the most common autoimmune disease in the USA, affecting approximately $2.2 \%$ of the population [1]. Psoriasis is associated with significant clinical and emotional morbidity; in particular, it impacts individuals' work and social lives and leads to reduced quality of life $[2,3]$. Individuals who do not experience acceptable levels of skin clearance with topical treatments and phototherapy or for whom topicals and phototherapy are not practical may be treated systemically with oral agents, such as methotrexate or ciclosporin, or with injectable biologics. Several biologics are currently indicated for psoriasis, including etanercept, adalimumab, infliximab and ustekinumab. The choice of the first-line biologic therapy, as well as subsequent treatment in those patients who fail or who are intolerant of the first-line biologic treatment, is not yet standardized, and data evaluating treatment-sequencing strategies are generally limited to estimates of efficacy for a biologic in individuals who have already failed treatment with any other biologic [4-6].

General guidance on when and how to include treatment sequencing in cost-effectiveness models is equally limited. Health technology assessment (HTA) guidelines for costeffectiveness modelling for chronic diseases from the National Institute for Health and Care Excellence (NICE) and other HTA agencies (e.g. the Pharmaceutical Benefits Advisory Committee [7], Canadian Agency for Drugs and Technologies in Health [8] and recent guidelines from the International Society for Pharmacoeconomics and Outcomes Research [9]) recommend performing cost-effectiveness analyses for as long as a new treatment impacts costs and health outcomes. However, these guidelines lack specific recommendations on best practice for selecting alternative treatment-sequencing strategies. In addition, many cost-effectiveness models for new treatments for chronic disease that have been submitted to NICE and other HTA agencies or that have been published in peerreviewed literature have not attempted to capture the impact of alternative assumptions about treatment sequencing on the cost effectiveness of new treatments.

In this paper, we present a systematic literature review and detailed analysis of the assumptions about treatment sequencing after failure on a first-line biologic included in published cost-effectiveness models of biologic therapy in adults 18 years of age or older with moderate to severe chronic plaque psoriasis. We compare these modelling assumptions with the recommendations from the most recent treatment guidelines for treatment after failure of first-line biologic therapy for North America and Western Europe, and we assess the value to decision makers of models that account for treatment sequencing after failure of the first biologic.

\section{Methods}

Systematic literature searches were undertaken for two specific topics: (1) cost-effectiveness models for biologic treatments for moderate to severe chronic plaque psoriasis; and (2) treatment guidelines for moderate to severe chronic plaque psoriasis.

\subsection{Literature Search}

This review was performed systematically in an unbiased manner by using a pre-specified protocol and an explicit, reproducible plan for literature search and synthesis (study protocol available on request from the authors). Economic analysis (cost minimization, cost-effectiveness analysis, cost-utility analysis and cost-benefit analysis) and clinical practice guidelines (CPGs), developed using rigorous methodology, were included in this review.

Searches to identify economic analyses were conducted from 1 January 1990 to 20 February 2013, to ensure that this review captured any economic evaluations for off-label biologic treatment of psoriasis that could have been published before that indication was approved. No limitations on publication language or geographic perspective were applied for the economic analysis searches. For the CPGs 
and treatment patterns, since no biologic was indicated for psoriasis prior to 2000, searches were initiated from 1 January 2000 to February 2013. No language limitation was applied during searches, although only those studies published in English for Europe or North America were included in the final review.

The following electronic databases were searched: MEDLINE, Embase, EconLit and the Cochrane Library. In addition, conference abstracts were searched from January 2011 to February 2013 on the web site of the World Congress of Dermatology as well as National Guideline Clearinghouse, NICE, Canadian Agency for Drugs and Technologies in Health, German Institute for Quality and Efficiency in Healthcare, and Pharmaceutical Benefits Advisory Committee web sites. Search terms included combinations of free text and Medical Subject Headings. Separate sets of terms were used for the health condition of interest (psoriasis), the treatments of interest (secukinumab, etanercept, adalimumab, infliximab and ustekinumab) and the study types of interest (cost minimization, costeffectiveness analysis, cost-utility analysis, economic models and practice guidelines) (Appendix 1 in ESM). Study inclusion was determined at two levels and in parallel by two researchers. At level 1, titles and abstracts of all identified articles were screened. Articles were excluded if their abstracts fit any of the pre-specified exclusion criteria: cost-of-illness or economic burden studies, subjects with types of psoriasis other than plaque psoriasis (e.g. pustular, erythrodermic, guttate psoriasis or psoriatic arthritis), children with psoriasis, case reports, letters, comments, editorials or reviews. The full texts of all papers determined to be eligible at level 1 were reviewed at level 2 to verify that they met the inclusion criteria. All disagreements at the two stages were resolved by consensus, with input from an experienced senior researcher. As the objective of this review was to evaluate to what extent the cost-effectiveness models followed treatment guidelines for biologic treatment after failure on conventional therapy, studies of the efficacy of different treatment patterns that did not include costeffectiveness analyses were excluded during level 2 screening.

\subsection{Data Extraction and Qualitative Synthesis}

For each eligible study that passed both levels of screening, data were extracted into evidence tables. A qualitative synthesis was performed by one researcher and verified with the original sources by a second researcher.

Two levels of data extraction and qualitative synthesis were undertaken for the cost-effectiveness model papers identified in the systematic search. First, summary information-authors, country, model design, comparators included, and whether or not the model included an active treatment alternative after failure of the first-line biologic_-was extracted for all of the identified models into an evidence table and a qualitative synthesis presented in the text. Second, for those models that included an active treatment alternative after failure of the first-line biologic, detailed information (where available) was extracted into an evidence table and a qualitative synthesis presented in the text on the choice of the subsequent active treatments, the method used to include them in the model, and the data sources and assumptions made for the efficacy of secondand third-line treatments.

For the treatment guidelines identified in the systematic searches, data extracted into an evidence table focused on recommendations for treatment of moderate to severe chronic plaque psoriasis where biologic therapy was indicated. Information was extracted from each guideline on the criteria for use of a first-line biologic, the recommended first-line biologic, the definition of failure of the first-line biologic, and what to do if the first-line biologic failed through lack of efficacy or intolerance. This information was summarized in the text and an assessment was made as to the extent to which the assumptions about treatment sequencing in the cost-effectiveness models were consistent with the recommendations in the treatment guidelines.

\section{Results}

\subsection{Study Identification and Characteristics}

A total of 882 records (economic studies 282; guidelines/ treatment patterns 600) were retrieved after the searches were performed, and 31 studies were included in the review. Of the included studies, 25 were economic analysis studies and seven were CPG publications (Fig. 1).

\subsection{Cost-effectiveness Analyses: Inclusion of Treatment Sequencing}

We reviewed 25 cost-effectiveness models focusing on biologic therapy for moderate to severe chronic plaque psoriasis [10-34] (Table 1). The cost-effectiveness models were for countries in Europe (11), North America (9) and South America (5). The types of models used included decision-tree models (12), empirical estimates based directly on clinical trial results (10) and Markov models (3). The first-line comparators in these cost-effectiveness models included only biologic agents (16), biologics or other systemic therapy (5) and biologics or other nonsystemic therapy (4). All of the models included only individuals with chronic plaque psoriasis; all but one model (which only included severe cases) included individuals with moderate or severe disease. 


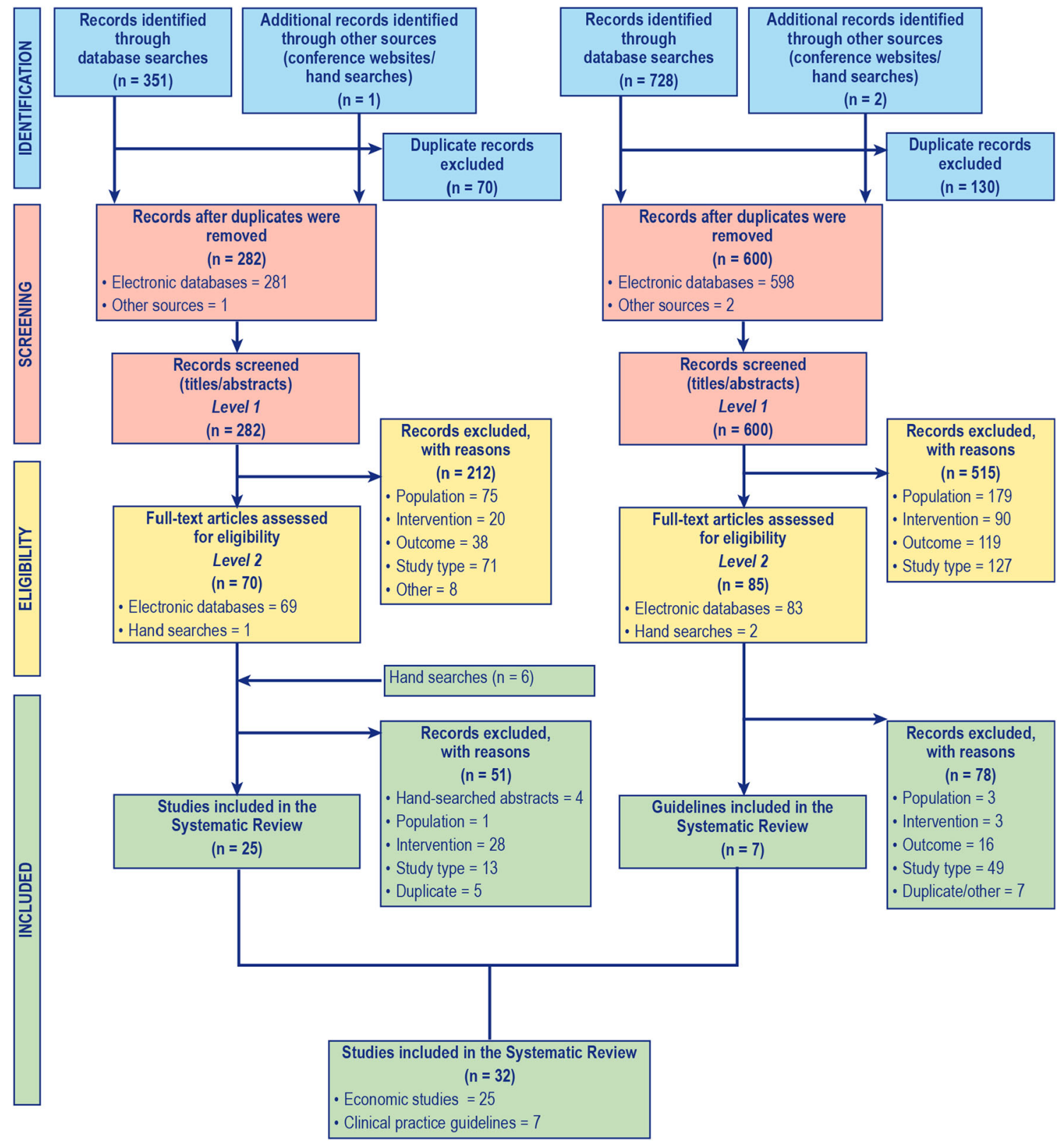

Fig. 1 PRISMA (Preferred Reporting Items for Systematic Reviews and Meta-analyses) flowchart for study inclusion and exclusion [economic studies (left) and guidelines reviews (right)]

The models varied in time horizon and whether they included treatment sequencing. In 15 of the 25 models reviewed, active treatment after failure of the first-line biologic was not considered. In 10 of these 15 models [12, $14,20,22,23,27-29,31,32]$, cost effectiveness was estimated as the cost per responder in a short-term analysis (varying from 12 weeks to 18 months), with discontinuation from the first-line biologic not explicitly considered in the model. In the other five models out of 15 models that did not include an active second-line treatment, cost effectiveness was estimated over a 10-year time horizon. In these five models, discontinuation from the first-line biologic was assumed to be followed by a switch to topical treatment [13] or nonsystemic treatment [24, 25], no further active treatment [26] or best supportive care [30].

In 10 of the 25 models reviewed, treatment sequencing with an active treatment after failure of the first-line biologic was explicitly included in the analysis $[10,11,15-19$, $21,33,34]$. The time horizons for the cost-effectiveness analyses in these models ranged from 96 weeks to 10 years. Five of the ten models that included an active treatment after failure of the first-line biologic were 
Table 1 Summary of economic analyses and their consideration of treatment sequencing after failure on the first biologic

\begin{tabular}{|c|c|c|c|c|}
\hline $\begin{array}{l}\text { Author, year } \\
\text { Country } \\
\text { Cost-year } \\
\text { Currency }\end{array}$ & $\begin{array}{l}\text { Analysis or } \\
\text { model type }\end{array}$ & Interventions & Patient characteristics & $\begin{array}{l}\text { Model consideration of treatment } \\
\text { sequencing after failure on the first } \\
\text { biologic }\end{array}$ \\
\hline $\begin{array}{l}\text { Alandete, } 2011[10] \\
\text { Colombia } \\
\text { Cost-year: NR } \\
\text { US \$ } \\
\text { (abstract and poster only) }\end{array}$ & $\begin{array}{l}\text { Decision } \\
\text { tree }\end{array}$ & $\begin{array}{l}\text { Etanercept, infliximab, } \\
\text { ustekinumab, adalimumab }\end{array}$ & $\begin{array}{l}\text { Patients with moderate to severe } \\
\text { plaque psoriasis }\end{array}$ & $\begin{array}{l}\text { Dose titration or switching to } \\
\text { alternative biologic with } \\
\text { treatment failure; time horizon } \\
2 \text { years }\end{array}$ \\
\hline $\begin{array}{l}\text { Anis et al., } 2011[11] \\
\text { USA } \\
2007 \text { US \$ }\end{array}$ & Empirical & $\begin{array}{l}\text { Adalimumab, etanercept, } \\
\text { infliximab, efalizumab, } \\
\text { alefacept }\end{array}$ & $\begin{array}{l}\text { Patients who have failed } \\
\text { conventional therapies }\end{array}$ & $\begin{array}{l}\text { Yes, optimal sequencing is } \\
\text { determined; time horizon } \\
\text { unknown; annualized results } \\
\text { presented }\end{array}$ \\
\hline $\begin{array}{l}\text { Blasco et al., } 2009[12] \\
\text { Spain } \\
2008 €\end{array}$ & $\begin{array}{l}\text { Decision } \\
\text { tree }\end{array}$ & $\begin{array}{l}\text { Etanercept, infliximab, } \\
\text { adalimumab, efalizumab }\end{array}$ & $\begin{array}{l}\text { Patients with moderate to severe } \\
\text { psoriasis }\end{array}$ & $\begin{array}{l}\text { No sequencing considered; cost per } \\
\text { responder at } 12 \text { weeks }\end{array}$ \\
\hline $\begin{array}{l}\text { Colombo et al., } 2009 \text { [13] } \\
\text { Italy } \\
2006 €\end{array}$ & $\begin{array}{l}\text { Decision } \\
\text { tree }\end{array}$ & Etanercept, topical treatment & $\begin{array}{l}\text { Patients with moderate to severe } \\
\text { plaque psoriasis }\end{array}$ & $\begin{array}{l}\text { No sequencing considered; } 10 \text {-year } \\
\text { time horizon; treatment failures } \\
\text { switch to topical treatment }\end{array}$ \\
\hline $\begin{array}{l}\text { de Portu et al., } 2010[14] \\
\text { Cost-year: NR } \\
\text { Italy } €\end{array}$ & Empirical & $\begin{array}{l}\text { Infliximab, etanercept, } \\
\text { adalimumab }\end{array}$ & $\begin{array}{l}\text { Patients with moderate to severe } \\
\text { plaque psoriasis not further } \\
\text { specified }\end{array}$ & $\begin{array}{l}\text { No sequencing considered; } \\
\text { 50-week time horizon; drug cost } \\
\text { per responder measured }\end{array}$ \\
\hline $\begin{array}{l}\text { Fernandes et al., } 2012 \text { [15] } \\
\text { Colombia, } \\
\text { Cost-year: NR } \\
\text { US \$ } \\
\text { (abstract only) }\end{array}$ & $\begin{array}{l}\text { Decision } \\
\text { tree }\end{array}$ & $\begin{array}{l}\text { Etanercept, infliximab, } \\
\text { ustekinumab, adalimumab }\end{array}$ & $\begin{array}{l}\text { Patients with moderate to severe } \\
\text { plaque psoriasis }\end{array}$ & $\begin{array}{l}\text { Therapy switch or discontinuation } \\
\text { evaluated at week } 24 \text {; details not } \\
\text { available in abstract }\end{array}$ \\
\hline $\begin{array}{l}\text { Fernandes et al., } 2012 \text { [16] } \\
\text { Venezuela, } \\
\text { Cost-year: NR } \\
\text { US \$ } \\
\text { (abstract only) }\end{array}$ & $\begin{array}{l}\text { Decision } \\
\text { tree }\end{array}$ & $\begin{array}{l}\text { Etanercept, infliximab, } \\
\text { ustekinumab, adalimumab }\end{array}$ & $\begin{array}{l}\text { Patients with moderate to severe } \\
\text { plaque psoriasis }\end{array}$ & $\begin{array}{l}\text { Therapy switch or discontinuation } \\
\text { evaluated at week } 24 \text {; details not } \\
\text { available in abstract }\end{array}$ \\
\hline $\begin{array}{l}\text { Fernandes et al., } 2012 \text { [17] } \\
\text { Brazil } \\
\text { Cost-year: NR } \\
\text { US \$ } \\
\text { (abstract only) }\end{array}$ & $\begin{array}{l}\text { Decision } \\
\text { tree }\end{array}$ & $\begin{array}{l}\text { Etanercept, infliximab, } \\
\text { ustekinumab, adalimumab }\end{array}$ & $\begin{array}{l}\text { Patients with moderate to severe } \\
\text { plaque psoriasis }\end{array}$ & $\begin{array}{l}\text { Therapy switch or discontinuation } \\
\text { evaluated at week } 24 \text {; details not } \\
\text { available in abstract }\end{array}$ \\
\hline $\begin{array}{l}\text { Fernandes et al., } 2012 \text { [18] } \\
\text { Argentina } \\
\text { Cost-year: NR } \\
\text { US \$ } \\
\text { (abstract only) }\end{array}$ & $\begin{array}{l}\text { Decision } \\
\text { tree }\end{array}$ & $\begin{array}{l}\text { Etanercept, infliximab, } \\
\text { ustekinumab, adalimumab }\end{array}$ & $\begin{array}{l}\text { Patients with moderate to severe } \\
\text { plaque psoriasis }\end{array}$ & $\begin{array}{l}\text { Therapy switch or discontinuation } \\
\text { evaluated at week 24; details not } \\
\text { available in abstract }\end{array}$ \\
\hline $\begin{array}{l}\text { Fernandes et al., } 2012 \text { [19] } \\
\text { Brazil } \\
\text { Cost-year: NR } \\
\text { US \$ } \\
\text { (abstract only) }\end{array}$ & $\begin{array}{l}\text { Decision } \\
\text { tree }\end{array}$ & $\begin{array}{l}\text { Etanercept, infliximab, } \\
\text { ustekinumab, adalimumab }\end{array}$ & $\begin{array}{l}\text { Patients with moderate to severe } \\
\text { plaque psoriasis }\end{array}$ & $\begin{array}{l}\text { Therapy switch or discontinuation } \\
\text { evaluated at week } 24 \text {; details not } \\
\text { available in abstract }\end{array}$ \\
\hline $\begin{array}{l}\text { Ferrandiz et al., } 2012 \text { [20] } \\
\text { Spain } \\
\text { Cost-year: NR } \\
€\end{array}$ & $\begin{array}{l}\text { Decision } \\
\text { tree }\end{array}$ & $\begin{array}{l}\text { Adalimumab, etanercept, } \\
\text { infliximab, ustekinumab }\end{array}$ & $\begin{array}{l}\text { Patients with moderate to severe } \\
\text { plaque psoriasis }\end{array}$ & $\begin{array}{l}\text { No sequencing considered; costs } \\
\text { per responder at } 24 \text { weeks }\end{array}$ \\
\hline $\begin{array}{l}\text { Greiner and Braathen, } 2009 \\
\text { [21] } \\
\text { Switzerland } \\
2006 \mathrm{CHF}\end{array}$ & $\begin{array}{l}\text { Decision } \\
\text { tree }\end{array}$ & $\begin{array}{l}\text { Infliximab, etanercept, } \\
\text { adalimumab, efalizumab, } \\
\text { alefacept }\end{array}$ & $\begin{array}{l}\text { Patients who have failed } \\
\text { conventional therapies }\end{array}$ & $\begin{array}{l}\text { Yes, optimal sequencing is } \\
\text { determined; time horizon } \\
36 \text { weeks }\end{array}$ \\
\hline
\end{tabular}


Table 1 continued

\begin{tabular}{|c|c|c|c|c|}
\hline $\begin{array}{l}\text { Author, year } \\
\text { Country } \\
\text { Cost-year } \\
\text { Currency }\end{array}$ & $\begin{array}{l}\text { Analysis or } \\
\text { model type }\end{array}$ & Interventions & Patient characteristics & $\begin{array}{l}\text { Model consideration of treatment } \\
\text { sequencing after failure on the first } \\
\text { biologic }\end{array}$ \\
\hline $\begin{array}{l}\text { Hankin et al., } 2005 \text { [22] } \\
\text { USA } \\
2004 \text { US \$ }\end{array}$ & Empirical & $\begin{array}{l}\text { Infliximab, etanercept, } \\
\text { alefacept, efalizumab, } \\
\text { methotrexate, ciclosporin, } \\
\text { acitretin, PUVA, UVB }\end{array}$ & $\begin{array}{l}\text { Patients with moderate to severe } \\
\text { plaque psoriasis }\end{array}$ & $\begin{array}{l}\text { No sequencing considered; 1-year } \\
\text { time horizon; annualized drug } \\
\text { and drug-related costs per } \\
\text { responder measured }\end{array}$ \\
\hline $\begin{array}{l}\text { Hankin et al., } 2010 \text { [23] } \\
\text { USA } \\
2008 \text { US \$ }\end{array}$ & Empirical & $\begin{array}{l}\text { Infliximab, etanercept, } \\
\text { adalimumab, alefacept, } \\
\text { efalizumab, methotrexate, } \\
\text { ciclosporin, PUVA, UVB }\end{array}$ & $\begin{array}{l}\text { Patients with moderate to severe } \\
\text { psoriasis }\end{array}$ & $\begin{array}{l}\text { No sequencing considered; 1-year } \\
\text { time horizon; annualized drug } \\
\text { and drug-related costs per } \\
\text { responder measured }\end{array}$ \\
\hline $\begin{array}{l}\text { Heinen-Kammerer et al., } \\
2007 \text { [24] } \\
\text { Germany } \\
\text { Cost-year: NR } \\
€\end{array}$ & $\begin{array}{l}\text { Decision } \\
\text { tree }\end{array}$ & $\begin{array}{l}\text { Etanercept, nonsystemic } \\
\text { therapy }\end{array}$ & $\begin{array}{l}\text { Patients with moderate to severe } \\
\text { plaque psoriasis }\end{array}$ & $\begin{array}{l}\text { No sequencing considered; } 10 \text {-year } \\
\text { time horizon; treatment failures } \\
\text { switch to nonsystemic treatment }\end{array}$ \\
\hline $\begin{array}{l}\text { Knight et al., } 2012 \text { [25] } \\
\text { Sweden } \\
2008 \text { Swedish kronor }\end{array}$ & $\begin{array}{r}\text { Markov } \\
\text { model }\end{array}$ & $\begin{array}{l}\text { Etanercept, adalimumab, } \\
\text { nonsystemic therapy }\end{array}$ & $\begin{array}{l}\text { Patients with moderate to severe } \\
\text { plaque psoriasis }\end{array}$ & $\begin{array}{l}\text { No sequencing considered; } 10 \text {-year } \\
\text { time horizon; treatment failures } \\
\text { switch to nonsystemic treatment }\end{array}$ \\
\hline $\begin{array}{l}\text { Lloyd et al., } 2009 \text { [26] } \\
\text { UK } \\
2006 £\end{array}$ & $\begin{array}{l}\text { Decision } \\
\text { tree }\end{array}$ & Etanercept, usual care & $\begin{array}{l}\text { Patients with moderate to severe } \\
\text { plaque psoriasis who are unable to } \\
\text { take standard systemic therapies }\end{array}$ & $\begin{array}{l}\text { No sequencing considered; } 10 \text {-year } \\
\text { time horizon; treatment failures } \\
\text { switch to usual care }\end{array}$ \\
\hline $\begin{array}{l}\text { Martin et al., } 2011 \text { [27] } \\
\text { USA } \\
\text { Cost-year: NR } \\
\text { US \$ }\end{array}$ & Empirical & Ustekinumab, etanercept & $\begin{array}{l}\text { Patients with moderate to severe } \\
\text { plaque psoriasis who were } \\
\text { candidates for phototherapy or } \\
\text { systemic therapy }\end{array}$ & $\begin{array}{l}\text { No sequencing considered; cost per } \\
\text { responder at } 16 \text { weeks }\end{array}$ \\
\hline $\begin{array}{l}\text { Menter and Baker, } 2005 \text { [28] } \\
\text { USA } \\
2003 \text { US \$ }\end{array}$ & Empirical & $\begin{array}{l}\text { Alefacept, efalizumab, } \\
\text { etanercept }\end{array}$ & $\begin{array}{l}\text { Patients with moderate to severe } \\
\text { plaque psoriasis }\end{array}$ & $\begin{array}{l}\text { No sequencing considered; cost for } \\
\text { treated population per responder } \\
\text { at } 18 \text { months }\end{array}$ \\
\hline $\begin{array}{l}\text { Nelson et al., } 2008 \text { [29] } \\
\text { USA } \\
2006 \text { US \$ }\end{array}$ & Empirical & $\begin{array}{l}\text { Etanercept, infliximab, } \\
\text { adalimumab }\end{array}$ & $\begin{array}{l}\text { Patients with moderate to severe } \\
\text { plaque psoriasis }\end{array}$ & $\begin{array}{l}\text { No sequencing considered; cost per } \\
\text { responder at } 12 \text { weeks }\end{array}$ \\
\hline $\begin{array}{l}\text { Pan et al., } 2011[30] \\
\text { Canada } \\
1999 \text { or } 2009 \text { Can } \$\end{array}$ & $\begin{array}{l}\text { Markov } \\
\text { model }\end{array}$ & Etanercept, ustekinumab & $\begin{array}{l}\text { Patients with severe plaque psoriasis } \\
\text { refractory to conventional systemic } \\
\text { therapy or phototherapy }\end{array}$ & $\begin{array}{l}\text { No sequencing considered; } 10 \text {-year } \\
\text { time horizon, treatment failures } \\
\text { switch to best supportive care }\end{array}$ \\
\hline $\begin{array}{l}\text { Pearce et al., } 2006[31] \\
\text { USA } \\
2003 \text { US \$ }\end{array}$ & Empirical & $\begin{array}{l}\text { Infliximab, etanercept, } \\
\text { adalimumab, alefacept, } \\
\text { efalizumab, methotrexate, } \\
\text { ciclosporin, PUVA, nUVB }\end{array}$ & $\begin{array}{l}\text { Patients with moderate to severe } \\
\text { plaque psoriasis }\end{array}$ & $\begin{array}{l}\text { No sequencing considered; costs } \\
\text { per successfully treated patient } \\
\text { and per failure at } 12 \text { weeks }\end{array}$ \\
\hline $\begin{array}{l}\text { Schmitt-Rau et al., } 2010 \text { [32] } \\
\text { Germany } \\
2009 €\end{array}$ & Empirical & $\begin{array}{l}\text { Adalimumab, etanercept, } \\
\text { infliximab, ustekinumab }\end{array}$ & $\begin{array}{l}\text { Patients with moderate to severe } \\
\text { plaque psoriasis }\end{array}$ & $\begin{array}{l}\text { No sequencing considered; costs } \\
\text { per responder at } 12 \text { weeks }\end{array}$ \\
\hline $\begin{array}{l}\text { Sizto et al., } 2009 \text { [33] } \\
\text { UK } \\
2005-2006 £\end{array}$ & Empirical & $\begin{array}{l}\text { Adalimumab, etanercept, } \\
\text { efalizumab, infliximab, } \\
\text { methotrexate, ciclosporin }\end{array}$ & $\begin{array}{l}\text { Patients with moderate to severe } \\
\text { plaque psoriasis }\end{array}$ & $\begin{array}{l}\text { Yes, optimal sequencing is } \\
\text { determined; time horizon } \\
\text { unknown; annualized results } \\
\text { presented }\end{array}$ \\
\hline $\begin{array}{l}\text { Woolacott et al., } 2006 \text { [34] } \\
\text { UK } \\
2003-2005 £\end{array}$ & $\begin{array}{r}\text { Markov } \\
\text { model }\end{array}$ & $\begin{array}{l}\text { Methotrexate, ciclosporin, } \\
\text { dimethyl fumarate, } \\
\text { etanercept, efalizumab }\end{array}$ & $\begin{array}{l}\text { Patients with moderate to severe } \\
\text { plaque psoriasis }\end{array}$ & $\begin{array}{l}\text { Yes, optimal sequencing is } \\
\text { determined; maximum time } \\
\text { horizon } 10 \text { years; annualized } \\
\text { results presented }\end{array}$ \\
\hline
\end{tabular}

Note: Conventional therapies included topical therapy, phototherapy and immune suppressants such as methotrexate or ciclosporin; failed therapy was defined as being unresponsive to or intolerant of or contraindicated for conventional therapy

$N R$ not recorded, $n U V B$ narrowband ultraviolet $\mathrm{B}, P U V A$ psoralen plus ultraviolet $\mathrm{A}, U V B$ ultraviolet $\mathrm{B}$ 
available only as abstracts and did not provide details of the treatment switches that were included [15-19]. These models included cost-effectiveness estimates for Colombia, Brazil (private and public perspective), Venezuela and Argentina; all were based on the same model structure and had a time horizon of 96 weeks. The abstract for each country stated, "Therapy continuation or switch was evaluated at week 24." The abstracts did not give any further information about the switch treatment options included at week 24 nor how they were accounted for in the analyses.

Treatment sequencing was included in five out of the ten models that included active treatment after failure of the first-line biologic with details provided of either the optimal sequencing strategy or the treatment pathways included (Table 2). Three of the five models (Anis et al. [11] [USA], Sizto et al. [33] [UK] and Woolacott et al. [34] [UK]) were all based on the same model structure (York) developed by Woolacott and colleagues [34]. An optimal sequencing of biologic therapy was generated in each of these papers on the basis of ordering the net benefits [34] or cost-effectiveness ratios [11,33] per unit of time for each biologic estimated separately, using treatments with higher net benefits or more favourable cost-effectiveness ratios earlier in the treatment sequence. All three models assumed that efficacy for each biologic was independent of the treatment history and that the biologic did not impact disease progression. To estimate the net benefit or cost effectiveness per unit time period for each biologic, the average annual costs and quality-adjusted life-years (QALYs) gained, compared with best supportive care, were estimated for individuals during the time they were taking the treatment (see Appendix 2 in ESM for the equations that were used to estimate the average annual costs and QALYs). QALYs gained were based on the impact of treatment on the Psoriasis Area and Severity Index (PASI) score, an index providing a single score between 0 and 70 , based on both the severity of the lesions and the body area affected. In the Woolacott and colleagues [34] analysis, an annual dropout rate of $20 \%$ and a maximum treatment duration of 10 years were assumed for patients who were successfully treated in the trial period with all treatments. In the Sizto and colleagues [33] study, no information was provided on the dropout rates and the maximum duration of treatment. In the Anis and colleagues [11] study, a dropout rate of $10 \%$ per year was used; no information was provided about the maximum duration of treatment. Although all of these studies estimated the optimal sequencing strategy, none of the studies estimated the net benefits or cost effectiveness associated with that strategy compared with alternative strategies. However, Woolacott and colleagues [34] provided an equation for estimating the net benefits for any given treatment strategy (e.g. A followed by $\mathrm{B}$ and then $\mathrm{C}$ ), assuming that patients who do not achieve PASI 75 (a reduction in the PASI score of $75 \%$ ) with each treatment nevertheless experience some gain in quality of life while still on the treatment before switching to the next treatment in the pathway:

$$
\begin{aligned}
\text { Net benefits }(\mathrm{A}, \mathrm{B}, \mathrm{C})= & \mathrm{NB}_{\mathrm{A}}+(1-\mathrm{PA} 75) \times \mathrm{NB}_{\mathrm{B}} \\
& +(1-\mathrm{PA75}) \times(1-\mathrm{PB} 75) \\
& \times \mathrm{NB}_{\mathrm{C}},
\end{aligned}
$$

where $\mathrm{NB}_{\mathrm{A}}, \mathrm{NB}_{\mathrm{B}}$ and $\mathrm{NB}_{\mathrm{C}}$ are the net benefits estimated for treatment $\mathrm{A}, \mathrm{B}$ and $\mathrm{C}$, respectively; PA75 and PB75 = probability of achieving a PASI 75 response or better with treatment $\mathrm{A}$ and $\mathrm{B}$, respectively.

The other two studies that included an active sequence of biologic treatments in their cost-effectiveness models estimated the cost effectiveness of alternative treatment sequences that included switches to specific second- and third-line treatment regimens after failure of the first-line biologic. The Alandete [10] study for Peru and Colombia was presented as a poster only, so details were limited. In that study, the first-line biologic treatments compared were adalimumab, etanercept (low or high dose), ustekinumab (low dose) or infliximab. The second-line biologics compared were ustekinumab (high dose), infliximab or etanercept (high dose), depending on the first-line treatment. The third-line options were ustekinumab (high dose) or best supportive care. A decision-tree model was used, with switches (or dose titration, for etanercept) allowed for lack of efficacy; switches also were allowed for adverse events or lack of tolerance after the first 12 weeks on any given therapy. The response rates for the second-line and thirdline active treatments were adjusted down, compared with the efficacy with first-line treatment for that biologic, but details of the data sources or adjustment method were not provided. The cost effectiveness for patients starting each first-line biologic therapy during the 2-year model period, measured as the incremental cost per PASI 75 responder compared with etanercept (low dose), was estimated on the basis of the response to treatment achieved at the end of the 2-year modelling period whether or not the patient remained on the initial treatment.

The Greiner and Braathen [21] study for Switzerland also used a decision-tree model to estimate the 36-week cost effectiveness of first-line treatment with different biologics, based on the Swiss requirement that nonresponders at 12 weeks to first-line biologic treatment discontinue from that treatment. In that study, five first-line biologic treatments were compared: infliximab, etanercept (high dose), adalimumab, efalizumab and alefacept. Individuals who failed the initial biologic at 12 weeks were switched in equal proportions to one of the other four biologics included in the analysis. The second-line biologic was assumed 
Table 2 Summary of sequencing methods in economic models that consider sequencing of biologic treatments

\begin{tabular}{|c|c|c|c|c|c|}
\hline $\begin{array}{l}\text { Author, } \\
\text { year }\end{array}$ & Study population & Interventions administered ${ }^{\mathrm{a}}$ & $\begin{array}{l}\text { Treatment-sequencing } \\
\text { method }\end{array}$ & $\begin{array}{l}\text { Efficacy assumptions for } \\
\text { subsequent lines of biologic } \\
\text { therapy }\end{array}$ & Clinical data sources \\
\hline $\begin{array}{l}\text { Alandete, } \\
2011[10]\end{array}$ & $\begin{array}{l}\text { Patients with } \\
\text { moderate or } \\
\text { severe } \\
\text { psoriasis } \\
\text { eligible for } \\
\text { treatment with } \\
\text { biologic } \\
\text { therapy }\end{array}$ & $\begin{array}{l}\text { First line: adalimumab, } \\
\text { etanercept (low dose or } \\
\text { high dose, continuous), } \\
\text { ustekinumab (low dose), } \\
\text { and infliximab } \\
\text { Second line: ustekinumab } \\
\text { (low or high dose), } \\
\text { infliximab } \\
\text { Third line: ustekinumab (high } \\
\text { dose), infliximab, } \\
\text { supportive therapy }\end{array}$ & $\begin{array}{l}\text { Decision tree with switching } \\
\text { at } 12 \text { weeks after initiating } \\
\text { first- or second-line therapy } \\
\text { or when adverse events } \\
\text { experienced } \\
\text { Time horizon: } 2 \text { years } \\
\text { Switching after first-line } \\
\text { failure to either } \\
\text { ustekinumab (high dose) or } \\
\text { infliximab, except for } \\
\text { individuals failing } \\
\text { infliximab (switch to } \\
\text { ustekinumab [high dose]) or } \\
\text { for those failing low dose } \\
\text { etanercept who switch to } \\
\text { etanercept high dose } \\
\text { Switching after second-line } \\
\text { failure to ustekinumab (high } \\
\text { dose) or best supportive } \\
\text { care }\end{array}$ & $\begin{array}{l}\text { Response on second- and } \\
\text { third-line biologic } \\
\text { therapies was adjusted } \\
\text { downwards from first-line } \\
\text { therapy efficacy; method } \\
\text { or data sources used to } \\
\text { make these adjustments } \\
\text { were not provided }\end{array}$ & $\begin{array}{l}\text { First-line efficacy } \\
\text { taken from a meta- } \\
\text { analysis of biologic } \\
\text { therapy clinical trials } \\
\text { by Hawkins et al., } \\
2009 \text { [35] }\end{array}$ \\
\hline $\begin{array}{l}\text { Anis et al., } \\
2011[11]\end{array}$ & $\begin{array}{l}\text { Patients with } \\
\text { moderate or } \\
\text { severe plaque } \\
\text { psoriasis who } \\
\text { have failed } \\
\text { conventional } \\
\text { therapy }\end{array}$ & $\begin{array}{l}\text { Adalimumab, etanercept (low } \\
\text { dose or high dose, } \\
\text { continuous), infliximab, } \\
\text { efalizumab, alefacept }\end{array}$ & $\begin{array}{l}\text { Optimal treatment sequencing } \\
\text { based on ranking of only } \\
\text { annualized cost- } \\
\text { effectiveness ratios (cost/ } \\
\text { QALY) for each biologic as } \\
\text { first-line therapy for time } \\
\text { period on the biologic }\end{array}$ & $\begin{array}{l}\text { Implicit assumption that } \\
\text { efficacy for second- or } \\
\text { third-line biologic is the } \\
\text { same as for first-line } \\
\text { biologic }\end{array}$ & $\begin{array}{l}\text { Clinical trials for } \\
\text { biologics-typically } \\
\text { biologic-naïve } \\
\text { individuals or a mix } \\
\text { of biologic-naïve } \\
\text { and biologic-failure } \\
\text { individuals }\end{array}$ \\
\hline $\begin{array}{l}\text { Greiner and } \\
\text { Braathen, } \\
2009[21]\end{array}$ & $\begin{array}{l}\text { Patients with } \\
\text { moderate or } \\
\text { severe plaque } \\
\text { psoriasis who } \\
\text { have failed } \\
\text { conventional } \\
\text { therapy }\end{array}$ & $\begin{array}{l}\text { Infliximab, etanercept (high } \\
\text { dose, continuous), } \\
\text { adalimumab, efalizumab, } \\
\text { alefacept }\end{array}$ & $\begin{array}{l}\text { Decision tree with } 36 \text {-week } \\
\text { time horizon based on } \\
\text { Swiss requirement that } \\
\text { nonresponders to biologic } \\
\text { therapy stop initial } \\
\text { treatment after } 12 \text { weeks; } \\
\text { modelled switch to any of } \\
\text { the other } 4 \text { biologics and } \\
\text { assumed that the patients } \\
\text { stayed on second-line } \\
\text { biologic for } 24 \text { weeks }\end{array}$ & $\begin{array}{l}\text { Explicit assumption that } \\
\text { efficacy for second- or } \\
\text { third-line biologic is the } \\
\text { same as for first-line } \\
\text { biologic for base case; } \\
\text { sensitivity analysis was } \\
\text { conducted with } 25 \% \text { and } \\
50 \% \text { reduction in PASI } \\
75 \text { response rates }\end{array}$ & $\begin{array}{l}\text { Clinical trials for } \\
\text { biologics—typically } \\
\text { biologic-naïve } \\
\text { individuals or a mix } \\
\text { of biologic-naïve } \\
\text { and biologic-failure } \\
\text { individuals }\end{array}$ \\
\hline $\begin{array}{l}\text { Sizto et al., } \\
2009[33]\end{array}$ & $\begin{array}{l}\text { Patients with } \\
\text { moderate or } \\
\text { severe plaque } \\
\text { psoriasis }\end{array}$ & $\begin{array}{l}\text { Adalimumab, etanercept (low } \\
\text { dose or high dose; } \\
\text { intermittent or continuous), } \\
\text { efalizumab, infliximab. } \\
\text { methotrexate, ciclosporin } \\
\text { (intermittent or continuous) }\end{array}$ & $\begin{array}{l}\text { Optimal treatment sequencing } \\
\text { based on ranking of only } \\
\text { annualized cost- } \\
\text { effectiveness ratios (cost/ } \\
\text { QALY) for each biologic as } \\
\text { first-line therapy for time } \\
\text { period on the biologic }\end{array}$ & $\begin{array}{l}\text { Implicit assumption that } \\
\text { efficacy for second- or } \\
\text { third-line biologic is the } \\
\text { same as for first-line } \\
\text { biologic }\end{array}$ & $\begin{array}{l}\text { Clinical trials for } \\
\text { biologics-typically } \\
\text { biologic-naïve } \\
\text { individuals or a mix } \\
\text { of biologic-naïve } \\
\text { and biologic-failure } \\
\text { individuals }\end{array}$ \\
\hline $\begin{array}{l}\text { Woolacott } \\
\text { et al., } \\
2006 \text { [34] }\end{array}$ & $\begin{array}{l}\text { Patients with } \\
\text { moderate or } \\
\text { severe plaque } \\
\text { psoriasis }\end{array}$ & $\begin{array}{l}\text { Methotrexate, ciclosporin, } \\
\text { dimethyl fumarate, } \\
\text { infliximab, etanercept (low } \\
\text { dose or high dose, } \\
\text { intermittent), efalizumab }\end{array}$ & $\begin{array}{l}\text { Optimal treatment sequencing } \\
\text { based on ranking of only } \\
\text { annualized cost- } \\
\text { effectiveness ratios (cost/ } \\
\text { QALY) for each biologic as } \\
\text { first-line therapy for time } \\
\text { period on the biologic }\end{array}$ & $\begin{array}{l}\text { Implicit assumption that } \\
\text { efficacy for second- or } \\
\text { third-line biologic is the } \\
\text { same as for first-line } \\
\text { biologic }\end{array}$ & $\begin{array}{l}\text { Clinical trials for } \\
\text { biologics-typically } \\
\text { biologic-naïve } \\
\text { individuals or a mix } \\
\text { of biologic-naïve } \\
\text { and biologic-failure } \\
\text { individuals }\end{array}$ \\
\hline
\end{tabular}

PASI Psoriasis Area and Severity Index

${ }^{a}$ Biologic dosing regimens included in the studies are as follows: adalimumab $80 \mathrm{mg}$ at week 0 then $40 \mathrm{mg}$ every other week starting at week 1 (except Sizto who assumed $40 \mathrm{mg}$ every other week); alefacept $15 \mathrm{mg} / \mathrm{week}$ for 12 weeks then 12 week break; efalizumab $1 \mathrm{mg} / \mathrm{kg}$ per week (except for Anis and Woolacott where first dose of $0.7 \mathrm{mg} / \mathrm{kg}$ then $1 \mathrm{mg} / \mathrm{kg}$ per week); etanercept low dose $25 \mathrm{mg}$ twice weekly; etanercept high dose $50 \mathrm{mg}$ twice weekly for 3 months followed by $25 \mathrm{mg}$ twice weekly (except for Sizto and Woolacott where high dose $50 \mathrm{mg}$ twice weekly); infliximab 3-5 mg/kg at weeks 0, 2 and 6 and then every 8 weeks; intermittent therapy is when treatment is only given until patient achieves remission, but is restarted after relapse; ustekinumab low dose $45 \mathrm{mg}$ at weeks 0 and 4, then every 12 weeks; ustekinumab high dose $90 \mathrm{mg}$ at weeks 0 and 4 , then every 12 weeks 
to be continued for the remaining 24-week model time horizon. Although in the base-case analysis, the efficacy of the second-line biologic was assumed independent of the treatment history, in a sensitivity analysis, the efficacy for the second-line biologic was reduced by either 25 or $50 \%$, compared with the efficacy estimated for the same biologic when used in first-line. First-line efficacy was taken from published, placebo-controlled clinical trials. Cost effectiveness was measured as the incremental cost per responder when compared with placebo at 36 weeks. The biologic treatment sequence with the lowest incremental cost per responder was considered to provide the best value for money in Switzerland. Changing the relative efficacy of second-line treatments did not change the ordering of the optimal biologic treatment sequence in this analysis.

\subsubsection{Treatment Guidelines: Recommendations for Treatment Sequencing}

We found seven North American and European psoriasis guidelines published in English (Table 3). These guidelines included two for North America [36-38] and five for Europe [39-44]. The guidelines provided recommendations for the place of biologics in treatment for psoriasis, recommendations for what to do if a first-line biologic fails, and other general comments on the use of biologics (Table 4). In the North American guidelines, biologics are indicated for first-line systemic therapy and may be used without prior failure on methotrexate or ciclosporin. However, in Europe, biologics are indicated only for patients who have failed nonbiologic systemic therapy, such as methotrexate or ciclosporin, and/or who have failed psoralen plus ultraviolet A. The guidelines follow the marketing indications, although the US guidelines [36] indicate that routine use of biologics typically occurs after failure of traditional systemic drugs, and both UK guidelines, developed by the British Association of Dermatologists [40] and by NICE [41], provide a specific definition of moderate to severe psoriasis [i.e. total PASI score $\geq 10$ and Dermatology Life Quality Index (DLQI) score $>10$ ].

Most of the guidelines point out that the mechanisms of action are different for the different biologics and fall into three main categories: (1) target pathogenic T cells (alefacept; no longer available); (2) tumour necrosis factor (TNF) antagonists (adalimumab, etanercept, infliximab); and (3) block interleukin 12/23 (ustekinumab). The British Association of Dermatologists guidelines [40] also recognize that TNF- $\alpha$ antagonists are pharmacologically distinct from each other.

Although none of the guidelines recommend any specific biologic for first-line use, most provide some guidance for selection of the first-line biologic. The Canadian [38], German [42] and NICE [41] guidelines do not provide any specific guidance for choice of the first-line biologic, although the NICE guidelines require a PASI score of 20 or greater and a DLQI score of 18 or greater in order for infliximab to be used first line. The US guidelines [36, 37] mention that for TNF- $\alpha$ antagonists, the magnitude of response is greatest for infliximab, followed by adalimumab and then etanercept. These guidelines also mention the possibility of lasting benefit from short-term treatment with alefacept and the lack of long-term safety

Table 3 Organizations with recent psoriasis guidelines

\begin{tabular}{|c|c|c|c|}
\hline Organization & URL/other reference & $\begin{array}{l}\text { Publication } \\
\text { date }\end{array}$ & Audience \\
\hline American Academy of Dermatology & $\begin{array}{l}\text { Menter et al., 2008; American Academy of } \\
\text { Dermatology Work Group et al., } 2011 \\
{[36,37]}\end{array}$ & 2008,2011 & Dermatologists \\
\hline Canadian Dermatology Association & $\begin{array}{l}\text { http://www.dermatology.ca/wp-content/ } \\
\text { uploads/2012/01/cdnpsoriasisguidelines. } \\
\text { pdf [38] }\end{array}$ & June 2009 & Dermatologists \\
\hline European Academy of Dermatology and Venereology & Pathirana et al., 2009 [39] & 2009 & $\begin{array}{l}\text { Dermatologists, health } \\
\text { insurers, health policy } \\
\text { makers }\end{array}$ \\
\hline British Association of Dermatologists & Smith et al., 2009 [40] & 2009 & Dermatologists \\
\hline $\begin{array}{l}\text { National Clinical Guidelines Centre, commissioned by } \\
\text { the National Institute for Health and Care Excellence }\end{array}$ & $\begin{array}{l}\text { http://guidance.nice.org.uk/CG153/ } \\
\text { Guidance [41] }\end{array}$ & $\begin{array}{l}\text { October } \\
2012\end{array}$ & $\begin{array}{l}\text { Primary care providers } \\
\text { and dermatologists }\end{array}$ \\
\hline German S3 Guidelines-update & Nast et al., 2012 [42] & 2012 & $\begin{array}{l}\text { Dermatologists, health } \\
\text { insurers, health policy } \\
\text { makers }\end{array}$ \\
\hline Spanish Academy of Dermatology and Venereology & Puig et al., 2009a, b [43, 44] & 2009 & Dermatologists \\
\hline
\end{tabular}

Note: Guidelines identified but not included because the languages of the publication were for the Netherlands (2009) or Portugal (2012) 
Table 4 Treatment guidelines: recommendations for treatment after failure of first-line biologic

\begin{tabular}{|c|c|c|c|}
\hline $\begin{array}{l}\text { Author } \\
\text { Country or region }\end{array}$ & $\begin{array}{l}\text { Recommendations for place of biologics } \\
\text { in therapy }\end{array}$ & $\begin{array}{l}\text { Recommendations post-first-line biologic } \\
\text { treatment failures }\end{array}$ & Other general comments on biologics \\
\hline $\begin{array}{l}\text { Menter et al., } 2008 \text { [36]; } \\
\text { American Academy of } \\
\text { Dermatology Work } \\
\text { Group et al., } 2011 \text { [37] } \\
\text { USA }\end{array}$ & $\begin{array}{l}\text { Biologics are indicated in the USA for } \\
\text { moderate or severe psoriasis } \\
\text { Biologic agents are routinely used when } \\
\text { one or more traditional systemic agents } \\
\text { fail to produce an adequate response or } \\
\text { are not tolerated because of adverse } \\
\text { effects or are unsuitable because of } \\
\text { comorbid conditions } \\
\text { Treatment algorithm has all systemic } \\
\text { monotherapy, both conventional and }\end{array}$ & $\begin{array}{l}\text { No specific sequence in which current } \\
\text { TNF- } \alpha \text { antagonists should be used, } \\
\text { although initial response, in order of } \\
\text { magnitude, is greatest for infliximab, } \\
\text { then adalimumab, then etanercept } \\
\text { Alefacept overall has lower efficacy, but } \\
\text { a subset of the psoriasis population may } \\
\text { have lasting benefit from short-term } \\
\text { treatment } \\
\text { Ustekinumab is newer, with less safety }\end{array}$ & $\begin{array}{l}\text { Three different mechanisms of action: } \\
\text { (1) target pathogenic T cells: alefacept } \\
\text { (can re-treat), efalizumab (do not } \\
\text { discontinue abruptly because of danger } \\
\text { of rebound or flare-now withdrawn); } \\
\text { (2) TNF antagonists: adalimumab (small } \\
\text { proportion lose efficacy over time), } \\
\text { etanercept, infliximab (infusion-related } \\
\text { reactions can be reduced with low dose } \\
\text { methotrexate); }\end{array}$ \\
\hline
\end{tabular}
monotherapy, both conventional and biologic, in the same line of treatment, after failure of topical therapy and UV therapy, if available

\section{Canadian Dermatology Association, 2009 [38] \\ Canada}

Pathirana et al., 2009 [39] Europe

Nast et al., 2012 [42] Germany

Puig et al., 2009a, b [43, 44]

Spain
Can use biologics (adalimumab, etanercept, infliximab, alefacept, ustekinumab) as first-line systemic therapy; do not have to be reserved for methotrexate or ciclosporin or failures

Biologics are indicated for individuals who have failed or are intolerant of systemic therapy with methotrexate, ciclosporin or PUVA

Biologics are indicated for those who have failed or are intolerant of systemic therapy with methotrexate, ciclosporin or PUVA

Infliximab, etanercept, adalimumab or ustekinumab are recommended as firstline biologic agents

Biologics (efalizumab, etanercept, infliximab, adalimumab) are indicated for individuals who have failed or are intolerant of systemic therapy with methotrexate, ciclosporin or PUVA

None of the biologic agents should be considered generally preferable to the others in the treatment of moderate to severe psoriasis on the basis solely of response rates published in clinical trials

Choice of specific biologic agent should be made on case-by-case basis for patients needing systemic treatment, depending on patient characteristics and comorbidities

\section{data}

Loss of response may occur over a year with TNF- $\alpha$ antagonists, necessitating combination treatment with phototherapy or methotrexate or switching from one biologic to another

Treatment algorithm presented has combination therapy after failure of monotherapy on any systemic therapy or phototherapy

No guidance on what to do after biologic failure

No guidance on what to do after biologic failure

Infliximab rapid onset is noted

"At present there is no clear step-by-step procedure or strict clinical algorithm for the treatment of psoriasis"

Criterion for modifying treatment is a PASI $<50$ response or a DLQI score of $>5$; recommended strategies for modifying treatment include increasing dose, reducing dose intervals, adding a topical agent, adding another systemic therapy or changing the drug

All biologics: response to treatment should be assessed at week 12 or 16 , and the patient should be switched to an alternative treatment if an improvement of at least $50 \%$ of the baseline PASI has not been achieved

Efalizumab: "When efalizumab treatment does not include a satisfactory response or has to be discontinued for any reason, an appropriate strategy for managing the transition may be to overlap treatment for a few weeks with another effective and fast-acting systemic therapy in order to prevent a possible rebound effect, particularly in patients considered to be nonresponders"

Etanercept: combination therapy with, for example, methotrexate can be useful after loss of initial response

Infliximab: increasing the dose or frequency of infliximab or combining with low dose methotrexate can be useful after loss of initial response

Adalimumab: intermittent therapy is not effective; treatment after loss of initial response is only $55 \%$ effective
(3) block IL-12/23: ustekinumab-longterm efficacy

Mentions that biologics have different mechanisms of action: (1) adalimumab, etanercept, infliximab; (2) alefacept; (3) ustekinumab

Mentions combination therapy with methotrexate under investigation with etanercept and possibly could be used with infliximab or alefacept based on use in other diseases

Low dose methotrexate is safe in combination with biologics in other diseases

Biologics have different mechanisms of action: (1) efalizumab; (2) etanercept, infliximab and adalimumab

Most important decision is whether to choose continuous or intermittent therapy with systemic agent; biologic agents are best adapted for continuous treatment

Treatment failure with a biologic is an indication for changing treatment or prescribing a combination regimen

When changing systemic therapy (biologic or conventional) because of adverse effects of lack of efficacy, different treatment strategies are possible, including substitution or overlapping therapies; a conventional treatment can be used to cover the transition between two biologic regimens 
Table 4 continued

\begin{tabular}{|c|c|c|c|}
\hline $\begin{array}{l}\text { Author } \\
\text { Country or region }\end{array}$ & $\begin{array}{l}\text { Recommendations for place of biologics } \\
\text { in therapy }\end{array}$ & $\begin{array}{l}\text { Recommendations post-first-line biologic } \\
\text { treatment failures }\end{array}$ & Other general comments on biologics \\
\hline $\begin{array}{l}\text { Smith et al., } 2009 \text { [40] } \\
\text { UK }\end{array}$ & $\begin{array}{l}\text { Must have severe disease, defined as PASI } \\
\geq 10 \text { and DLQI }>10 \text {, and have failed or } \\
\text { be intolerant to or contraindicated for } \\
\text { phototherapy or conventional systemic } \\
\text { therapy } \\
\text { During the transition from conventional } \\
\text { systemic therapy to biologic therapy, } \\
\text { there should be a 4-week wash-out } \\
\text { period for individuals with stable } \\
\text { disease (or a minimal dose of } \\
\text { methotrexate); for those with unstable } \\
\text { disease, conventional therapy may need } \\
\text { to be continued until the therapeutic } \\
\text { efficacy of the biologic is established } \\
\text { TNF antagonists are recommended as } \\
\text { first-line biologics for individuals } \\
\text { meeting the criteria for a biologic; } \\
\text { recommendation of which TNF } \\
\text { antagonist to use first, based on patient } \\
\text { assessment, is as follows: } \\
\text { - Stable plaque psoriasis: use etanercept } \\
\text { or adalimumab } \\
\text { - Rapid control needed: use adalimumab } \\
\text { or infliximab } \\
\text { - Unstable disease: use infliximab }\end{array}$ & $\begin{array}{l}\text { A second TNF antagonist can be used } \\
\text { when there is primary or secondary } \\
\text { failure on the initial TNF antagonist } \\
\text { Ustekinumab should be reserved for use in } \\
\text { patients with severe psoriasis who fulfil } \\
\text { the stated disease severity requirements } \\
\text { and for whom TNF antagonist therapy } \\
\text { has failed or is contraindicated } \\
\text { Combination therapy of a biologic with } \\
\text { methotrexate may be effective when } \\
\text { efficacy is limited, but the evidence } \\
\text { supporting this is generally weak } \\
\text { When switching from one biologic to } \\
\text { another, overlap should be avoided, with } \\
\text { the recommended interval being four } \\
\text { times the drug's half-life }\end{array}$ & $\begin{array}{l}\text { Included two targets for action: (1) } \\
\text { infliximab, adalimumab, etanercept; and } \\
\text { (2) ustekinumab, with different } \\
\text { synthesis methods within the first } \\
\text { category } \\
\text { Only limited efficacy data on use of a } \\
\text { second biologic therapy where the first } \\
\text { has failed Although infliximab, } \\
\text { adalimumab and etanercept all act to } \\
\text { block TNF, they are pharmacologically } \\
\text { distinct. Thus, failure to respond to one } \\
\text { TNF antagonist may not preclude } \\
\text { response to a second. This is supported } \\
\text { by the findings of a small, open-label } \\
\text { study and retrospective case-cohort } \\
\text { review demonstrating the efficacy of } \\
\text { adalimumab following etanercept failure } \\
\text { Of note: approximately a third of patients } \\
\text { who entered into the ustekinumab RCTs } \\
\text { had been previously treated with } \\
\text { biologic therapy (predominantly TNF } \\
\text { antagonists), and this did not influence } \\
\text { therapeutic outcome }\end{array}$ \\
\hline $\begin{array}{l}\text { National Institute for } \\
\text { Health and Care } \\
\text { Excellence, } 2012 \text { [41] } \\
\text { England and Wales }\end{array}$ & $\begin{array}{l}\text { Patients must have disease defined by the } \\
\text { following: } \\
\text { A total PASI } \geq 10 \text { and a DLQI }>10 \text { (for } \\
\text { adalimumab, etanercept and } \\
\text { ustekinumab) or a total PASI } \geq 20 \text { and a } \\
\text { DLQI }>18 \text { (for infliximab); and } \\
\text { Have not responded to standard systemic } \\
\text { therapies, including ciclosporin, } \\
\text { methotrexate and PUVA; or } \\
\text { Are intolerant of, or have a } \\
\text { contraindication to, these treatments }\end{array}$ & $\begin{array}{l}\text { Consider changing to an alternative } \\
\text { biological drug if any of the following: } \\
\text { The psoriasis does not respond adequately } \\
\text { to a first biological drug at } 10 \text { weeks } \\
\text { after starting treatment for infliximab, } \\
12 \text { weeks for etanercept and } 16 \text { weeks } \\
\text { for adalimumab and ustekinumab } \\
\text { (primary failure); or } \\
\text { The psoriasis initially responds adequately } \\
\text { but subsequently loses this response } \\
\text { (secondary failure); or } \\
\text { The first biological drug cannot be } \\
\text { tolerated or becomes contraindicated }\end{array}$ & $\begin{array}{l}\text { There is a definite clinical benefit of a } \\
\text { second biological drug, especially when } \\
\text { compared with no care; however, there } \\
\text { is no robust evidence to recommend } \\
\text { using biological drugs in a particular } \\
\text { order } \\
\text { For adults in whom there is an inadequate } \\
\text { response to a second biological drug, } \\
\text { seek supraspecialist advice from a } \\
\text { clinician with expertise in biological } \\
\text { therapy }\end{array}$ \\
\hline
\end{tabular}

DLQI Dermatology Life Quality Index, $I L$ interleukin, PASI Psoriasis Area and Severity Index, PUVA psoralen plus ultraviolet A, RCT randomized controlled trial, $T N F$ tumour necrosis factor, $U V$ ultraviolet

data for ustekinumab. The European S3-guidelines [39] do not recommend alefacept (no longer available) or efalizumab (taken off the market because of fatal brain infections) for first-line use, and they mention that infliximab provides the most rapid response. The Spanish guidelines [43, 44] recommend that the choice of biologic agent should be made on a case-by-case basis, depending on patient characteristics and comorbidities. The British Association of Dermatologists guidelines [40] recommend the use of a TNF- $\alpha$ antagonist as the first-line biologic, the choice of which depends on whether or not the disease is stable and whether or not rapid control is needed.

The guidelines vary in their definition of failure on firstline biologic therapy and in their recommendations for what to do after failure on the first-line biologic. The Canadian [38] and European S3-guidelines [39] provide no definition of failure and no guidance for what to do after biologic failure, although the European guidelines mention that the efficacy of combination treatment with methotrexate plus etanercept, infliximab or alefacept is under study. The US guidelines [36, 37] state that there is no specific sequencing for biologics but recognize that loss of response may occur after a year on TNF- $\alpha$ antagonists, necessitating combination treatment with phototherapy or methotrexate or switching to another biologic. However, the treatment algorithm presented in the most recent US guidelines [37] shows combination therapy as the treatment of choice after failure of first-line systemic monotherapy. The German guidelines [42] provide criteria for modifying treatment if a patient has a PASI $<50$ response or a DLQI score of greater than 5 . The German recommendations for modifying treatment include increasing the dose, reducing dose intervals, adding a topical agent, adding another systemic therapy or changing the drug. They also mention that low dose methotrexate is safe in combination with biologics in other diseases. The Spanish guidelines [43, 44] 
recommend assessing the response to biologic therapy at weeks 12 through 16 and switching to an alternative treatment regimen if the PASI response is less than 50. Alternative treatment regimens may include dose increases, change in interval between doses and combination treatment with methotrexate for infliximab and etanercept. The British Association of Dermatologists guidelines [40] suggest that a second TNF- $\alpha$ antagonist can be effective after failure of a first-line TNF- $\alpha$ antagonist. These guidelines recommend reserving ustekinumab for use only in individuals with severe psoriasis for whom TNF- $\alpha$ antagonists have failed. The British Association of Dermatologists guidelines mention the possibility of combination therapy with methotrexate but indicate that the evidence for efficacy is weak [40]. The NICE guidance [41] states that there is a definite clinical benefit from a second biologic drug but that there is no robust evidence for choosing an order for use of biologics. NICE does not mention the option of combination treatment after failure to respond to a second biologic but suggests that specialist care is needed [41].

\section{Discussion}

All of the guidelines we reviewed [36-44] suggested that if the first biologic fails, a second biologic may be used either as monotherapy or in combination with methotrexate, although the guidelines indicated that there were only limited data supporting the use of combination therapy with methotrexate in psoriasis. For the most part, the psoriasis treatment guidelines did not recommend any specific order of use of the biologics or any specific treatment-sequencing pattern.

The five cost-effectiveness models that included treatment sequencing and provided enough detail to assess their methodology and assumptions [10, 11, 21, 33, 34] generally were consistent with the treatment guidelines that recommended switching to alternative biologic treatments. The five cost-effectiveness models with a 10-year time horizon that assumed a return to nonsystemic treatment after failure of the first biologic were not consistent with current treatment guidelines [13, 24-26, 30]. None of the cost-effectiveness models considered combination therapy with a biologic and methotrexate, which was mentioned as a possible combination regimen by some treatment guidelines [37, 39, 40, 42-44]. However, there were limited data for the efficacy of this combination, and the combination is not an authorized indication for treatment, making it difficult to include in a cost-effectiveness model.

The issue of whether or not including active second- and third-line treatment affected the cost-effectiveness results for the initial biologic treatment was considered in only one model [10]. The poster concluded that the results from a previous model, which did not include treatment sequencing, were different, but not enough information was available from the poster to assess these differences. Clearly, the order, the efficacy and the costs assumed for the first-, second- and third-line treatments will impact the cost-effectiveness estimates for different treatmentsequencing strategies. However, as Woolacott and colleagues [34] demonstrated in their HTA, there are thousands of possible treatment sequences that could be compared. Therefore, the task of estimating the cost effectiveness of all the possible treatment sequences, compared with the next most effective or most costly treatment sequence, would be impractical. Thus, comparisons of selected hypothetical treatment sequences, as modelled by Greiner and Braathen [21] and Alandete [10], or estimation of optimal treatment sequencing based on net benefits or cost effectiveness for each individual biologic $[11,33,34]$ may be the most practical approaches.

A limitation of all of the models that included treatment sequencing is the very limited availability of clinical trial data to assess the efficacy of second- or third-line treatment with a biologic after failure of a previous biologic therapy. Four of the five models that provided details of the efficacy of second- or third-line treatments assumed the same efficacy, wherever in the treatment sequence the drug was used, for their base-case analyses. The fifth model [10] indicated that reduced efficacy was assumed but did not provide any information on the values used or the method used to derive them. In addition, the Greiner and Braathen [21] study, which assumed equal efficacy for the base-case, tested the sensitivity of the results to an assumption of reduced efficacy for second-line treatment with a biologic.

Most of the clinical trial data available were for first-line biologic therapy in patients who were biologic naïve or for a mix of patients who were biologic naïve and biologic failures. The efficacy for those patients who have previously failed a biologic was not reported for some of the clinical trials. However, these data were published for other trials. For example, a small subgroup analysis of biologic failures in a head-to-head study of etanercept and ustekinumab [6] showed that both etanercept and ustekinumab were efficacious in biologic failures but that the efficacy was lower in individuals who had failed biologics previously than in those who were biologic naïve. In contrast, Smith and colleagues [40] stated in the British Association of Dermatologists guidelines that approximately one third of the patients in the ustekinumab clinical trials had previously failed a TNF- $\alpha$ antagonist and that efficacy was similar in individuals who had failed a biologic compared with the efficacy in those naïve to biologic therapy. In addition, case series data and observational studies have shown efficacy of second-line TNF- $\alpha$ 
antagonists in individuals who have previously failed treatment with a TNF- $\alpha$ antagonist $[4,5]$.

While there are only limited data and guidelines for treatment sequencing after failure on the first-line biologic, treatment sequencing is common in clinical practice. If patients receive a TNF antagonist as first-line biologic treatment and fail, failure may occur because the TNF antagonist was not sufficiently potent, because the patient had poor adherence or because the patient developed antibodies. If the last reason applies, then switching to a different TNF antagonist is reasonable; if the first reason applies, then switching from a weaker to a more potent TNF antagonist, or adding a second agent such as a methotrexate, would be appropriate. Alternatively, switching to another class of agent; interleukin 17 or interleukin 23 might be appropriate. Conversely, if ustekinumab were used as the first-line biologic, then switching to a TNF antagonist would be clinically reasonable. For the most part, these switching decisions are based on data from first-line treatment studies, supplemented by data from the small number of clinical trial and observational studies in patients who have failed treatment on their first biologic. In addition, as response to therapy is quite variable among patients with psoriasis, identification of pharmacogenomic markers has the potential improve management of patients by identifying those who should be treated with a modified dose or alternative treatments [45]. The value of pharmacogenomic testing could also be considered in cost-effectiveness models in the future.

The lack of clinical trial data to assess the efficacy of second- or third-line treatment with biologics introduces additional uncertainty to cost-effectiveness models that include treatment sequencing. However, the assumption in a long-term cost-effectiveness model that individuals who fail the first-line biologic return to best supportive care, which does not include systemic therapy, is unlikely to reflect current treatment practice, which includes dose titration and switching to alternative treatment regimens. Including treatment sequencing and estimating the impact of alternative sequences in future cost-effectiveness models may increase the usefulness of the estimates to health care decision makers.

The strengths of this systematic review include identification of all published economic models and recent treatment guidelines for first-line biologic treatment for moderate to severe chronic plaque psoriasis. The limitations of the systematic review include the following: although no language limitation was applied during the searches, only English-language articles were included in the final review; the assumptions about treatment sequencing were not described in all of the studies that were identified; and unpublished models were not included.

\section{Conclusions}

The findings from this study indicate that, although treatment sequencing pathways are recommended in treatment guidelines and are likely common in clinical practice, costeffectiveness models of first-line biologic therapies have generally not included such pathways. This omission is partly due to the lack of data on the efficacy and safety of subsequent lines of treatment. A systematic review of published data on the efficacy of treatment after failure of the first-line biologic and/or additional clinical studies could provide such data. Another reason is the added model complexity because of the many possible alternative sequencing pathways. One way to include treatment sequencing would be to use the method for estimating the costs and QALYs gained for different treatment sequences suggested by Woolacott and colleagues [34] and described in our article. For example, a model could be designed that allows for titration of the first-line biologic as well as switching and titration with a second-line regimen after failure of the first regimen. This type of model, if it is populated with credible data on the efficacy and safety of subsequent treatments and if the results are provided for different possible treatment sequences, would provide useful information for decision makers, especially as biosimilar versions of some of the biologics become available.

Acknowledgements and Funding Disclosures Josephine Mauskopf received funding to conduct this study though a contract between Novartis Pharmaceuticals and her employer, RTI Health Solutions. Novartis Pharmaceuticals is developing biologic drugs for the treatment of moderate to severe psoriasis. She has also received funding through her employer from Wyeth/Pfizer, who market a biologic drug for psoriasis.

Doreen McBride received funding to conduct this study though a contract between Novartis Pharmaceuticals and her employer, RTI Health Solutions. Novartis Pharmaceuticals is developing biologic drugs for the treatment of moderate to severe psoriasis.

Miny Samuel received funding to conduct this study though a contract between Novartis Pharmaceuticals and her employer, RTI Health Solutions. Novartis Pharmaceuticals is developing biologic drugs for the treatment of moderate to severe psoriasis.

Usha Mallya is an employee of Novartis Pharmaceuticals. Novartis Pharmaceuticals is developing biologic drugs for the treatment of moderate to severe psoriasis.

Steven Feldman received consulting support for this study from Novartis Pharmaceuticals. Novartis Pharmaceuticals is developing biologic drugs for the treatment of moderate to severe psoriasis. He has also received speaking, research and/or consulting support from Novartis, Abbott, Amgen, Janssen and Pfizer.

All authors contributed to the conceptualization and design of the study, review of the study search protocol and outline, interpretation of the results, and writing and review of the manuscript. Miny Samuel, Doreen McBride and Josephine Mauskopf prepared the search protocol, performed the database searches and level 1 and 2 screening with help from other RTI-HS personnel, and abstracted the data included in the article.

Josephine Mauskopf acts as overall guarantor for the manuscript content. 
Open Access This article is distributed under the terms of the Creative Commons Attribution Noncommercial License which permits any noncommercial use, distribution, and reproduction in any medium, provided the original author(s) and the source are credited.

\section{References}

1. National Psoriasis Foundation. Statistics. 2013. http://www. psoriasis.org/netcommunity/learn_statistics. Accessed 2 Jul 2013.

2. Rapp SR, Feldman SR, Exum ML, et al. Psoriasis causes as much disability as other major medical diseases. J Am Acad Dermatol. 1999;41(3 Pt 1):401-7.

3. Hazard E, Cherry SB, Lalla D, et al. Clinical and economic burden of psoriasis. Manag Care Interface. 2006;19(4):20-6.

4. Papoutsaki M, Chimenti MS, Costanzo A, et al. Adalimumab for severe psoriasis and psoriatic arthritis: an open-label study in 30 patients previously treated with other biologics. J Am Acad Dermatol. 2007;7(2):269-75.

5. Strober S, Spitzer TR, Lowsky R, et al. Translational studies in hematopoietic cell transplantation: treatment of hematologic malignancies as a stepping stone to tolerance induction. Semin Immunol. 2011;23(4):273-81.

6. Griffiths CE, Strober BE, van de Kerkhof P, ACCEPT Study Group, et al. Comparison of ustekinumab and etanercept for moderate-to-severe psoriasis. N Engl J Med. 2010;362(2): $118-28$.

7. Australian Government, Department of Health and Ageing. Guidelines for preparing submissions to the Pharmaceutical Benefits Advisory Committee (version 4.3). 2008. http://www. health.gov.au/internet/main/publishing.nsf/content/AECB791C29 482920CA25724400188EDB/\$File/PBAC4.3.2.pdf. Accessed 2 Jul 2013.

8. Canadian Agency for Drugs and Technologies in Health. Guidelines for the economic evaluation of health technologies, 3rd edn. 2006. http://www.cadth.ca/media/pdf/186_Economic Guidelines_e.pdf. Accessed 2 Jul 2013.

9. Caro JJ, Briggs AH, Siebert U, ISPOR-SMDM Modeling Good Research Practices Task Force, et al. Modeling good research practices-overview: a report of the ISPOR-SMDM Modeling Good Research Practices Task Force-1. Value Health. 2012;15(6):796-803.

10. Alandete JC. Effect of treatment switch on the cost-effectiveness of biologics in psoriasis in Peru and Colombia. Value Health. 2011;14(3):A58.

11. Anis AH, Bansback N, Sizto S, et al. Economic evaluation of biologic therapies for the treatment of moderate to severe psoriasis in the United States. J Dermatolog Treat. 2011;22(2):65-74.

12. Blasco AJ, Lázaro P, Ferrándiz C, et al. Efficiency of biologic agents in the treatment of moderate to severe psoriasis [article in Spanish]. Actas Dermosifiliogr. 2009;100(9):792-803.

13. Colombo GL, Di Matteo S, Peris K, et al. A cost-utility analysis of etanercept for the treatment of moderate-to-severe psoriasis in Italy. Clinicoecon Outcomes Res. 2009;1:53-9.

14. de Portu S, Del Giglio M, Altomare G, et al. Cost-effectiveness analysis of TNF- $\alpha$ blockers for the treatment of chronic plaque psoriasis in the perspective of the Italian health-care system. Dermatol Ther. 2010;23(Suppl 1):S7-13.

15. Fernandes RA, Takemoto MLS, Amaral LM, et al. Economic analysis of etanercept as continuous or paused therapy in therapy in moderate to severe psoriasis from a public perspective in Colombia. Value Health. 2012;15(4):A252.
16. Fernandes RA, Takemoto MLS, Amaral LM, et al. Economic analysis of etanercept as continuous or paused therapy in moderate to severe psoriasis from a public perspective in Venezuela. Value Health. 2012;15(4):A251-2.

17. Fernandes RA, Takemoto MLS, Amaral LM, et al. Economic analysis of etanercept as continuous or paused therapy in moderate to severe psoriasis from a private perspective in Brazil. Value Health. 2012;15(4):A251.

18. Fernandes RA, Takemoto MLS, Amaral LM, et al. Economic analysis of etanercept as continuous or paused therapy in moderate to severe psoriasis from a public perspective in Argentina. Value Health. 2012;15(4):A252.

19. Fernandes RA, Takemoto MLS, Amaral LM, et al. Economic analysis of etanercept as continuous or paused therapy in moderate to severe psoriasis from a public perspective in Brazil. Value Health. 2012;15(4):A252.

20. Ferrandiz C, Garcia A, Blasco AJ, et al. Cost-efficacy of adalimumab, etanercept, infliximab and ustekinumab for moderateto-severe plaque psoriasis. J Eur Acad Dermatol Venereol. 2012;26(6):768-77.

21. Greiner RA, Braathen LR. Cost-effectiveness of biologics for moderate-to-severe psoriasis from the perspective of the Swiss healthcare system. Eur J Dermatol. 2009;19(5):494-9.

22. Hankin CS, Feldman SR, Szczotka A, et al. A cost comparison of treatments of moderate to severe psoriasis. Drug Benefit Trends. 2005; 17(5):200-14.

23. Hankin CS, Bhatia ND, Goldenberg G, et al. A comparison of the clinical effectiveness and cost-effectiveness of treatments for moderate to severe psoriasis. Drug Benefit Trends. 2010;22(1): $17-27$.

24. Heinen-Kammerer T, Daniel D, Stratmann L, et al. Cost-effectiveness of psoriasis therapy with etanercept in Germany. J Dtsch Dermatol Ges. 2007;5(9):762-8.

25. Knight C, Mauskopf J, Ekelund M, et al. Cost-effectiveness of treatment with etanercept for psoriasis in Sweden. Eur J Health Econ. 2012;13(2):145-56.

26. Lloyd A, Reeves P, Conway P, et al. Economic evaluation of etanercept in the management of chronic plaque psoriasis. Br J Dermatol. 2009;160(2):380-6.

27. Martin S, Feldman SR, Augustin M, et al. Cost per responder analysis of ustekinumab and etanercept for moderate to severe plaque psoriasis. J Dermatolog Treat. 2011;22(3):138-43.

28. Menter A, Baker T. Cost-efficacy analysis of biological treatments in psoriasis: an 18-month assessment. J Med Econ. 2005;8(1-4):139-46.

29. Nelson AA, Pearce DJ, Fleischer AB Jr, et al. Cost-effectiveness of biologic treatments for psoriasis based on subjective and objective efficacy measures assessed over a 12-week treatment period. J Am Acad Dermatol. 2008;58(1):125-35.

30. Pan F, Brazier NC, Shear NH, et al. Cost utility analysis based on a head-to-head phase 3 trial comparing ustekinumab and etanercept in patients with moderate-to-severe plaque psoriasis: a Canadian perspective. Value Health. 2011;14(5):652-6.

31. Pearce DJ, Nelson AA, Fleischer AB, et al. The cost-effectiveness and cost of treatment failures associated with systemic psoriasis therapies. J Dermatolog Treat. 2006;17(1):29-37.

32. Schmitt-Rau K, Rosenbach T, Radtke MA, et al. Cost-effectiveness of biological therapy in remission induction of moderate to severe plaque psoriasis. Dermatology. 2010;221(3):236-42.

33. Sizto S, Bansback N, Feldman SR, et al. Economic evaluation of systemic therapies for moderate to severe psoriasis. Br J Dermatol. 2009;160(6):1264-72.

34. Woolacott N, Hawkins N, Mason A, et al. Etanercept and efalizumab for the treatment of psoriasis: a systematic review. Health Technol Assess. 2006;10(46):1-iv. 
35. Hawkins NS, Huntley A, Eaton J. Meta-analysis of biologic therapies for the treatment of moderate to severe psoriasis. Presented at the ISPOR 14th Annual International Meeting, Orlando, May 2009.

36. Menter A, Gottlieb A, Feldman SR, et al. Guidelines of care for the management of psoriasis and psoriatic arthritis, section 1: overview of psoriasis and guidelines of care for the treatment of psoriasis with biologics. J Am Acad Dermatol. 2008;58(5): $826-50$.

37. American Academy of Dermatology Work Group, Menter A, Korman NJ, Elmets CA, et al. Guidelines of care for the management of psoriasis and psoriatic arthritis, section 6: guidelines of care for the treatment of psoriasis and psoriatic arthritis: casebased presentations and evidence-based conclusions. J Am Acad Dermatol. 2011;65(1):137-74.

38. Canadian Dermatology Association. Infliximab versus methotrexate, etanercept, adalimumab, and ustekinumab for plaque psoriasis: a review of the comparative clinical efficacy, safety and cost effectiveness. 2012. http://www.cadth.ca/media/pdf/htis/aug2012/RC0369\%20Infliximab\%20Final.pdf. Accessed 2 Jul 2013.

39. Pathirana D, Ormerod AD, Saiag P, et al. European S3-guidelines on the systemic treatment of psoriasis vulgaris. J Eur Acad
Dermatol Venereol. 2009;23(Suppl 2):1-70. Erratum in: J Eur Acad Dermatol Venereol. 2010;24(1):117-18.

40. Smith CH, Anstey AV, Barker JN, et al. British Association of Dermatologists' guidelines for biologic interventions for psoriasis 2009. Br J Dermatol. 2009;161(5):987-1019.

41. National Institute for Health and Care Excellence. Psoriasis: assessment and management of psoriasis. Clinical guideline: methods, evidence and recommendations. 2012. http://guidance. nice.org.uk/CG153/Guidance/pdf/English. Accessed 2 Jul 2013.

42. Nast A, Boehncke WH, Mrowietz U, et al. S3-guidelines on the treatment of psoriasis vulgaris (English version). Update. J Dtsch Dermatol Ges. 2012;10(Suppl 2):S1-95.

43. Puig L, Carrascosa JM, Daudén E, et al. Spanish evidence-based guidelines on the treatment of moderate-to-severe psoriasis with biologic agents. Actas Dermosifiliogr. 2009;100(5):386-413.

44. Puig L, Bordas X, Carrascosa JM, et al. Consensus document on the evaluation and treatment of moderate to severe psoriasis, Spanish Psoriasis Group of the Spanish Academy of Dermatology and Venereology. Actas Dermosifiliogr. 2009;100(5):277-86.

45. O'Reilly DD, Rahman P. Pharmacogenetics of psoriasis. Pharmacogenomics. 2011;12:87-101. 